\title{
FRANZISCEAN CADASTRE IN LANDSCAPE STRUCTURE RESEARCH: A SYSTEMATIC REVIEW
}

\author{
Martin Dolejš (i] ${ }^{1}$, Michal Forejt [i] ${ }^{2}$ \\ ${ }^{1}$ Faculty of Science, Jan Evangelista Purkyně University in Ústí nad Labem, Czechia \\ ${ }^{2}$ Faculty of Environmental Sciences, Czech University of Life Sciences Prague, Praha, Czechia
}

Manuscript received: October 16, 2018

Revised version: March 7, 2019

\begin{abstract}
Dolejš M., Forejt M., 2019. Franziscean cadastre in landscape structure research: a systematic review. Quaestiones Geographicae 38(1), Bogucki Wydawnictwo Naukowe, Poznań, pp. 131-144. 8 figs, 1 table.

ABSTRACT: Historical and archival sources are of cardinal importance in landscape research addressing the processes and course of landscape changes in European regions. The Franziscean cadastre from the $19^{\text {th }}$ century is among the most widely used historical sources in Central Europe. We identified 1440 records, finally providing 104 articles reporting the use of the Franziscean cadastre for in-depth analyses in order to identify (i) the practice of the cadastral data processing, (ii) purpose and spatial extent of the study, (iii) use of complementary sources and (iv) particular land use/ land cover classes under study. We have found the increasing attention towards the Franziscean cadastre as a source for landscape research reflected by the doubling number of records in the past decade with majority of the case studies located in Czechia (79), followed by Austria (9) and Italy (3). We have identified the trends in the use in landscape trajectory research and application to hydrology, agriculture and forestry. As regards the data processing, several issues connected with the methodology or design of the records were found (e.g. geographic information system processing description and data source specification). We further problematize the suitability of the supplementary data used and conclude our review with a set of recommendations to contribute to the discussion on the methodology of landscape reconstruction with historical datasets.
\end{abstract}

KEY WORDS: landscape reconstruction, land use land cover, historical maps, stable cadastre, Franciscan cadastre

Corresponding author: Martin Dolejš, martin.dolejs@ujep.cz

\section{Introduction}

Changes in the landscape structure are recognized as having a significant environmental impact on a global scale (Foley et al. 2005, Rockström et al. 2009). The historical sources, in particular historical map sources, are of growing importance in the fields of environmental history (Woitschová 2017) and land use reconstruction (Yang et al. 2014, Fuchs et al. 2015). They enable scholars to research and extrapolate the data necessary for the evaluation of the past states of the environment that are closely connected with land use change. Historical maps depicting different phenomena were created for many purposes. The environmental history and land use reconstruction refer in particular to maps presenting the land use and land cover (e.g. forestry maps, topographical and cadastral maps). Cadastral maps are of use in researching different geographical issues from Europe (Affek 2015, Agnoletti 2007, Bender et al. 2005, Hamre et al. 2007, Raška et al. 2017) and the New World (Kain, Baigent 1992). We focused the attention of this review on one of 
the oldest cadastral map source that covers a significant part of Central Europe in detailed scale - the Franziscean Cadastre (FC).

Despite the overall high thematic resolution (number of land use/land cover (LULC) classes), broad spatial extent (Central Europe) and detailed mapping scale (1:2880) of the Franziscean cadastre, historical map sources are generally burdened with potential shortcomings that have to be taken into account when dealing with historical data. Leyk et al. (2005) and Kaim et al. (2014) divide possible sources of uncertainty into three categories of

1. production oriented uncertainty (field survey and map reproduction errors),

2. transformation oriented uncertainty (GIS transformation, georeferencing and digitization errors) and

3. application oriented uncertainty (possible errors based, for example, on different semantics of LULC classes).

Yang et al. (2014) added the issue of

1. vagueness (or missing) mapping criteria (e.g. the instruction for surveyors),

2. differences in land use land cover categorization in historical and current map sources and

3. the delimitation of the boundary between similar LULC classes (for this particular issue, see Forejt et al. 2018).

The critical reflection of the map source is, therefore, needed due to possible intentional errors in mapping that are often connected with military purposes, tax fraud or the projective purpose of maps (Woitschová 2017). Despite these ambiguities in the use of old cadastral maps, to the extent of our knowledge, there has not been a study devoted to systematically reviewing the practice of their current use.

Reflecting on the methodological issues raised above, this study aims to evaluate the use of the Franziscean cadastre in the academic publications (records) in order to identify the practice concerning the handling of the historical source by the authors. We are addressing the questions of

1. How the authors use the spatial and attribute data of the FC in the means of landscape reconstruction?

2. What is the primary theme and purpose of their study?

3. What other (if any) historical/current sources are employed in the research?
4. What land use land cover classes are they focusing on (what is the level of generalization?)

5. What is the spatial extent and regional dedication of the studies?

In order to answer these questions, we adopted an approach of systematic review.

\section{Context and content of Franziscean cadastre}

The Franziscean cadastre (named after the Austrian Emperor Francis I) is a land register produced for the former Austrian Empire between 1817 and the 1880s (Feucht 2008, Timár, Biszak 2010). The Fanziscean cadastre cover at least partly current Czechia, Slovakia, Austria, Poland, Slovenia, Hungary, Ukraine, Croatia, Romania, Bosnia, and Serbia. The creation of the new cadastre was set in 1817 with an edict (ÖNB 2018) of Emperor Franz I. The cadastre was created from scratch, although the previous land taxation system valid in the Austrian Empire was based on Josephian mapping (1780s), which was the first measured cadastre in Austrian history. In 1810s it was easier to persuade the government to start new mapping, because at the same time, so called $2^{\text {nd }}$ military mapping (middle-scaled topographical maps) was starting to be mapped in the Empire and the two projects used partly common triangulation.

The methodology for the cadastre mapping was first described in 1818 and was further adjusted in 1824 and then in 1865 . Thus the methodology, incl. the map legend, was not unified for the whole Empire (Krčmářová 2015). The Cassini-Soldner's cylindrical transversal projection was determined as a cartographic projection. The mapping was done mostly at the scale of 1:2880 (one Vienna square inch on the map was equal to one Lower Austrian acre in the field) or some parts in 1:720, 1:1440, or 1:5760. The minimal mapping unit was set at 25 square fathoms, which is equal to approximately $90 \mathrm{~m}^{2}$ (Ebel 2004). The cadastre uses up to 40 land use classes, incl. 10 agroforestry land use classes (Krčmářová, Jeleček 2017).

Ideally, every cadastral district has available maps from three series:

1. Indication scratches produced right in the field usually during summer on small, hard paper desks with all information needed for further registry, 
2. Original maps based on the indication scratches made in office during winter as well as

3. Compulsory Imperial imprints made as lithographic copies from the original maps (Ebel 2004).

Apart from the maps, the Franciscan cadastre consists of a written registry of land and building parcels and many documents of valuation, such as the Yield Value Protocol, containing much detailed, yet not standardized information (Krčmárová, Arnold 2016). The Franciscan cadastre is an example of the rising need for public control of land administration and tax collection in the Modern period (Bumba 2007, Dale, McLaughlin 2000). For its enormous preciseness, from the first fiscal purposes, the Franciscan Cadastre started to be used as an important technical and legal basis (Bumba 2007).

\section{Methods}

\section{Record selection process}

For the purposes of the review process, the Preferred Reporting Items for Systematic Reviews and Meta-Analyses (PRISMA) workflow (Moher et al. 2009) was adopted. The recommended review process consists of four stages:

1. Identification (number of records found),

2. Screening (exclusion of duplicates),

2. Eligibility (exclusion of full texts based on eligibility criteria), and

3. Inclusion (final count of reviewed full texts records).

We searched the databases of the Web of Science (WoS), SCOPUS and Google Scholar (GS). We have included the Google Scholar database because of the availability of full text searches that allow us to find the results that does not use the keywords in fields queried by WoS or SCOPUS. The analysed records were obtained via institutional access to major databases (WoS, SCOPUS). The institutional access was not used in case of journals and sources with open access policy. The process of all data manipulation (identification, screening, eligibility and inclusion) was conducted by both authors with consecutive cross-check of individual records.

The search for the records in the databases was found to be more difficult due to the use of different terms for the Franziscean cadastre. We presume the existence of studies (records) that do not explicitly title the used source (FC or alternative term), and thus not all papers (records) using the source were captured (e.g. Raška et al. 2016). There are a majority of records using the term Stable or its versions (Stabile, Stabilnî) that refers to unification (stabilization) of the quota for taxation (based on soil fertility and LULC class) in all parts of monarchy (ÖNB 2018) by the newly established Franziscean cadastre. Versions of the term Stable were employed mainly by Czech or Slovak authors. On the other hand, terms referring to the Franziscean/Franciscan or Austrian cadastre were used in few Czech works and exclusively by authors from other countries. Therefore, we have performed the query with eight individual keywords in order to cover possible local variations indicating use of FC (Franziszeischer kataster, Franciscian cadastre, Stable cadastre, Stabile cadastre, Franciscan cadastre, Františkánský katastr, Stabilní katastr, Franziscean cadastre and Austrian cadastre). We used query operators in order to search for a whole statement (i. e. Fransiscan together with Cadastre). The starting year was not set. Records were collected until publishing date of February 1, 2018.

We identified 1440 records in total (WoS - 37, SCOPUS - 64, GS - 1339) matching abovementioned keywords. Despite the effort to localize all records, 98 records were not available as full texts and 18 only as abstract. Therefore, this records were removed from further screening process. All records were later automatically checked for duplicity (286 duplicates found) and were manually checked for eligibility based on the following criteria:

1. The records have to be an original research article, conference proceedings, book chapter, book or review. Therefore, diploma theses, project reports, grey literature and other sources were excluded from further analysis.

2. For the sake of reproducibility of the results by international community the language of the records has to be English or bilingual (but with an accurate translation; therefore, articles with only an English abstract or summary were excluded).

3. Records have to use any part of the Franziscean cadastre and consecutively work with 
spatial or tabular data inferred from the FC. Records that only refer to or mention the FC as a source or use maps as figures to indicate the location (e.g. location for archaeological prospection) were excluded.

4. There has to be a full text of the record published.

The manual check for eligibility resulted in 104 records for further in-depth analysis. For full transparency, supplementary material 2 provides a complete list of the records used in the study (available through the corresponding author).

\section{Data extraction and processing}

For each record, we manually extracted the set of 21 features/questions based on the analysis of full texts (see Supplement 1). All features/ questions were tested in the preliminary (pilot) review on the minor subset of the database in order to test and clarify the features/questions. Features form four distinctive groups. Firstly, the general bibliographic information such as the year of publication and type of output (e.g. article, book, review) was used. The second group consists of attributes aimed towards the purpose of the study and the types of the Franziscean cadastre's sources used in the studies, such as differentiation to cadastral maps or the written records of the cadastre. The third group refers to the methodology or manipulation of data, in particular to complementary data and methods of LULC classification and extraction. The fourth category describes the spatial scale of the researched studies.

The final structure of the review table and consecutive analysis of the data were conducted in $\mathrm{R}$ (R Core Team 2017) software package. The major group of the analysis forms frequency tables of the researched features (Wickham 2011). In order to find the patterns of frequently used complementary data sources (supplement 1 - Other map and data sources), the data mining method of eclat for frequent pattern mining (Hahsler et al. 2005) was applied. The principle of the eclat algorithm lies in the identification of the individual data (map and other sources in our case) that are often involved in studies together (e.g. 10\% of the studies applies source A together with source $\mathrm{B}$ and $\mathrm{C})$. The association rules were limited to at least 3\% support. In other words, the association of datasets used in the records were accepted and visualized if used in at least four records. All provided figures were created in $\mathrm{R}$ package ggplot2 (Wickham 2009).

\section{Results}

\section{Bibliographic information and localization of the records}

Among the 104 records eligible for in-depth analysis, the majority formed the original research articles (92), six book chapters and six conference proceedings. No reviews were found that were suitable according to our eligibility criteria. The use of the Franziscean cadastre in research has been growing over the last two decades. We found a significant rise (Fig. 1) in the records published after 2012 (more than 10 for almost all years until 2018). According to our findings, the dominant group of records is localised in Czechia. For any year except 2000 and 2004-2006, there was at least one record with a peak in 2017 with eighteen records.

The majority of records localised to Czechia consenting with the frequency of the terms used for the retrieval of the record (Fig. 2). There are significant differences between the frequency of use of Stable Cadastre (which is used mainly in Czech and Slovakian records) and the other keywords such as Franziscean or Franciscan cadastre. In order to cover the other possible keywords associated with Franziscean cadastre source, we applied the German and Czech translation involved (e.g. Franziszeischer Kataster,

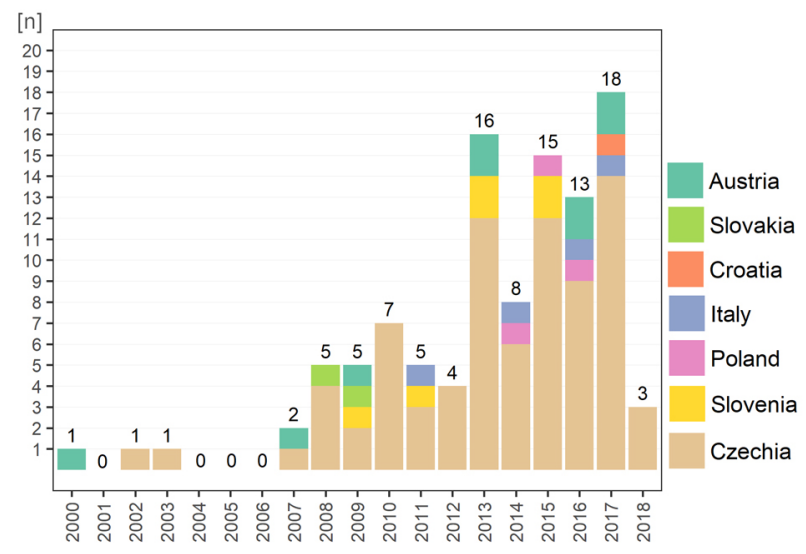

Fig. 1. Publication frequency and the localization of the record. 


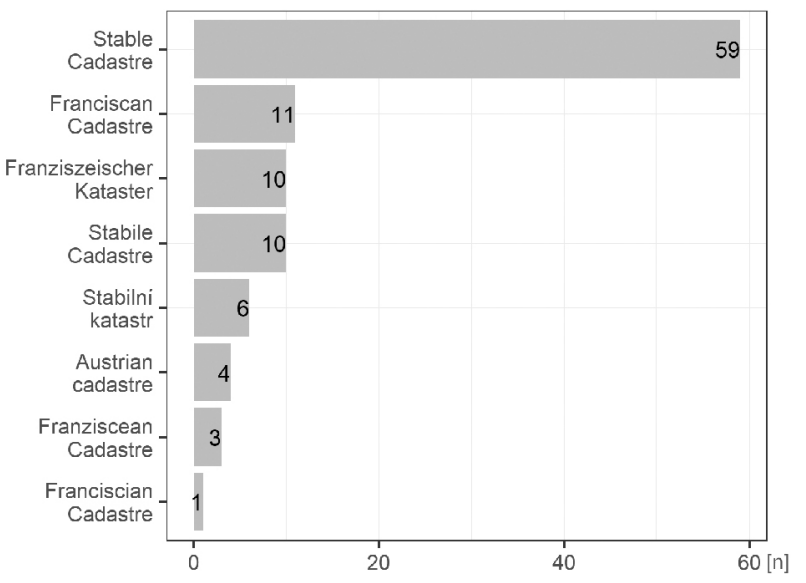

Fig. 2. Terms used for retrieval of the record.

Stabilní katastr, see Supplement 1 for full list) resulting in less than ten records. The Czech term Františkánský katastr appeared in the preliminary stages of the initial search, but there were no eligible studies in the final subset of 104 records.

The frequency of the keywords noted in the records resulted in no significant outlier. There are two keywords used ten times (Czech Republic and GIS) that reflect the current trend in the analysis of spatial data in geographical information systems and the dominance in the localisation of records (see also Fig. 1). Other frequently used keywords refer to land use or land use changes $(n=10)$, landscape structure $(n=4)$ and the European landscape convention $(n=4)$.

\section{Purpose of the study and general source}

In order to cover and clarify the different purposes of the reviewed records, we introduced seven categories based on the detailed information about the aim of the full texts involved in the study. The 35 records were categorized first into a general category of landscape change consisting of studies aimed at the development of land use and land cover without an interest in any particular LULC class or landscape feature (e.g. Bičík et al. 2010, Harvey et al. 2014). Other issues in this category included the persistent landscape features (features found in the same location in different time segments; e.g. Skaloš, Kašparová 2012), slope movements (Bíl et al. 2014), localization of mining areas (Beranová et al. 2017), ecological network design (Sklenička, Charvátová, 2003) and the identification of post-industrial features in the landscape (Kolejka 2010). The second category $(n=23)$ was focused on water bodies, streams and rivers. This group represents studies where old maps helped in the reconstruction of the river channel (e. g. Hohensinner et al. 2013, Scorpio et al. 2018) localization of extinct and persistent ponds (Pavelková et. al. 2016), modelled the potential water pollution (Glavan et al. 2013) or reflects the impact of amelioration interventions (Tlapáková et al. 2013). Studies focused on agricultural land $(n=17)$ elaborated the losses or localization of individual subcategories of agricultural LULC classes such as vineyards (Žiberna 2015), arable land (Szturc et al. 2017) or meadows and pastures. Special attention was given to the development/ reconstruction of agroforestry classes (Forejt et al. 2017, Krčmářová, Jeleček 2017) or water retention of the landscape based on the agricultural land use development (Karásek et al. 2015). The special subcategory focused on the social metabolism and flows of material and energy (Krausmann 2008, Fraňková, Cattaneo 2018). The development of forest or forestry management were classified as a standalone fourth group $(n=12)$ with the work aiming at forest and non-forest wooded vegetation (Skaloš et al. 2014, Troll, Ostafin 2016), acreage change of forest stands (Treml, Migoń 2015) or changes in forest management practices (Szabó, Hédl 2013). The fifth to seventh categories were rather minor and are represented by a (5) 3D reconstruction, (6) ownership and property rights and a (7) demography category. The category dealing with the localization of extinct settlements (Pacina, Holá 2014), paths (Svobodová, Hájek 2017) or urban forms (Popelka, Dědková 2014) were usually modelled $(n=8)$ by the $3 D$ reconstruction methods. Ownership fragmentation (Sklenička et al. 2017), ownership and taxation (Affek 2015) or tax relief due to meteorological extremes (Dolák et al. 2015) were categorized in another category $(n=4)$. Lastly, there were demographic studies $(\mathrm{n}=2)$ aimed at fertility (Breschi et al. 2014) or migration rates (Quaranta 2011), included to seventh category.

\section{Methodology and data manipulation used in records}

\section{Time periods involved in the records}

The distribution of the origination date of the data and maps employed in the studies (Fig. 3) spans from the $16^{\text {th }}$ century to the current time 


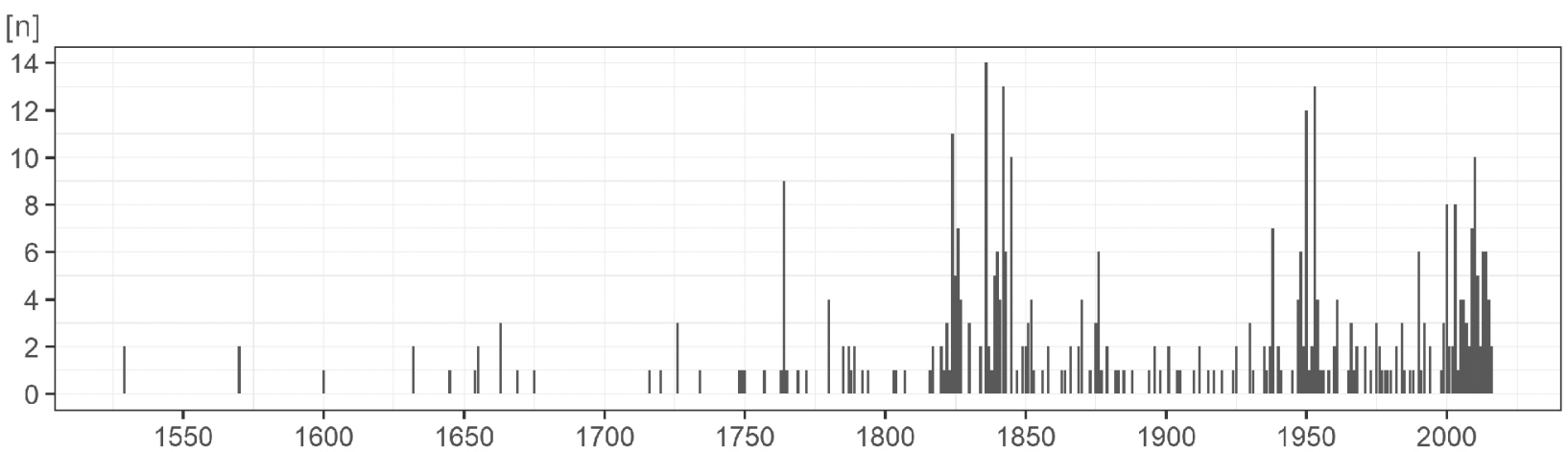

Fig. 3. Map and other sources dating frequency (note: figure include the FC).

period - ranging exactly from 1529 to 2016 . We can observe the densification of the used sources with apparent peaks around the years 1840, 1950 and after 2000.

Similarly, to the distribution of the origination date of the data, the distribution of the number of time points included in the records (Fig. 4) speaks for the most frequent use of three time points. The frequency of time points decreasing towards higher numbers of time points applied. As regards the outliers, we found 10 records with just one time point. These studies are mostly based on written registry records (or protocols) reconstructing the past pattern or societal demands. On the other hand, there were studies that gathered more than ten chronological data sources. These outlying records are represented by outcomes from extensive projects or detailed idiographic research in small scale but with an attentive historical sources search in both cases.

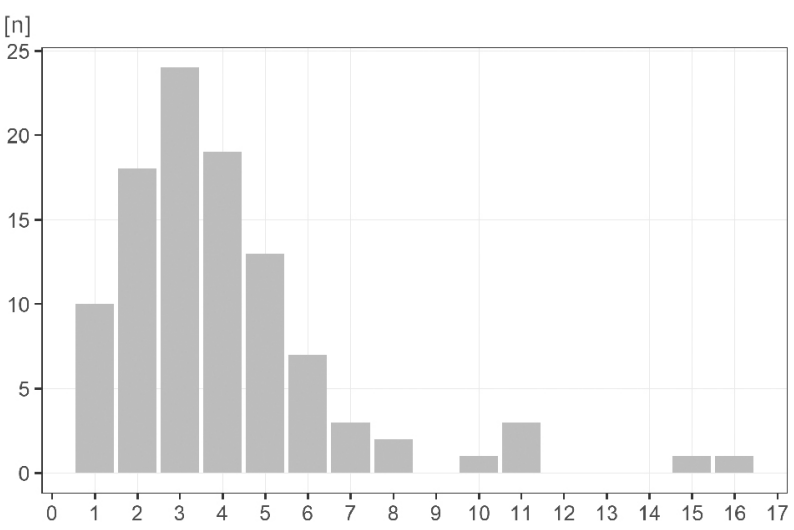

Fig. 4. Number of time points involved in the records (note: figure include the FC).

\section{LULC classes processed}

Concerning the LULC classes that were in the scope of the authors, we observed three distinctive subcategories. Firstly, there are studies that have no special interest in LULC with zero classes (Fig. 5). These records dealt with ownership, demography and fluxes of material and energy. Secondly, there were a majority of studies $(n=42)$ with just one category of LULC researched. Records in this category were related to the development of water bodies and rivers, forest stands and management and specific subcategories of LULC such as non-forest and non-agricultural vegetation. Thirdly, we distinguished the category with two and more LULC classes $(n=48)$. Studies in this category researched the development of the landscape in general or with the particular aim of selecting similar LULC subclasses (i.e. water bodies and rivers, coniferous and deciduous forests, etc.)

The qualitative structure of the involved LULC classes was addressed by frequency analyses divided according to the general class of LULC and its subclasses. As shown in Table 1, general classes such as forest, built-up or arable land were prevailing in the frequency of occurrence. The robust LULC categorization (thematic resolution) of the Franziscean cadastre was, therefore, often generalized (e.g. merger of coniferous and deciduous forests). On the other hand, the reflection

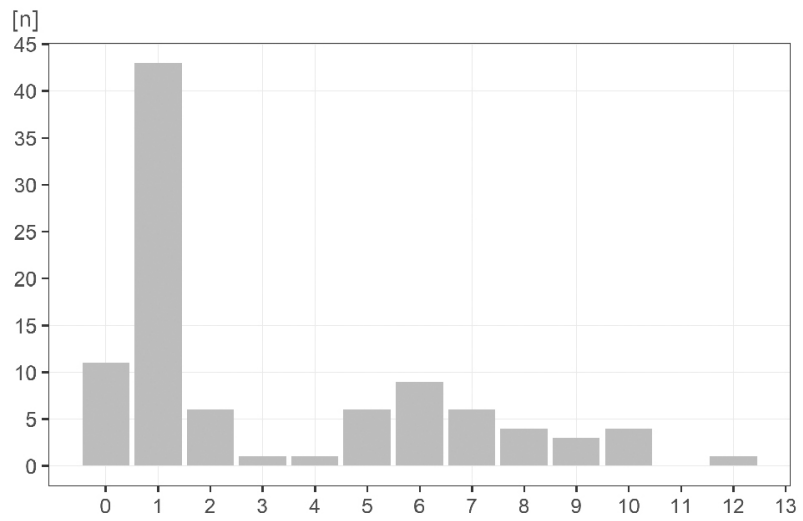

Fig. 5. Number of LULC classes employed in the record. 
Table 1. Frequency table of LULC classes.

\begin{tabular}{|l|c|}
\hline \multicolumn{1}{|c|}{ LULC class } & Frequency \\
\hline Built-up areas (yards) & 36 \\
\hline Forest & 39 \\
\hline Coniferous forests & 1 \\
\hline Deciduous forests & 1 \\
\hline Coppice woods & 1 \\
\hline Slash and Burn areas & 1 \\
\hline Agricultural land & 3 \\
\hline Arable land & 30 \\
\hline Arable land with trees & 2 \\
\hline Arable land with vineyards & 1 \\
\hline Arable land with olive trees & 1 \\
\hline Orchards & 14 \\
\hline Vineyards & 12 \\
\hline Vineyards with trees & 1 \\
\hline Vineyards with olive trees & 1 \\
\hline Hop fields & 2 \\
\hline Meadows and Pastures & 10 \\
\hline Meadows & 18 \\
\hline Meadows with trees (fruit trees) & 5 \\
\hline Pastures & 13 \\
\hline Pastures with trees (fruit trees) & 5 \\
\hline Water bodies (lakes, fish ponds) & 28 \\
\hline Water streams, rivers & 18 \\
\hline Gardens & 15 \\
\hline Non forest woody vegetation & 13 \\
\hline Roads, paths & 9 \\
\hline Swamps, wetlands & 7 \\
\hline Barren land & 6 \\
\hline Mining sites, Rocks & 4 \\
\hline Others & 21 \\
\hline Administrative boundaries & 6 \\
\hline LULC classes not extracted & \\
\hline
\end{tabular}

of detailed LULC classes such as meadows with fruit trees or arable land with trees indicate the interest in particular detailed LULC classes alone (see also Fig. 5).

As regards the part of the Franziscean cadastre used, we have looked for the use of map sources, a written registry or their combinations. The majority of the researched records $(n=58)$ did not explicitly mention the particular source of the FC or we were unable to recognize the particular source

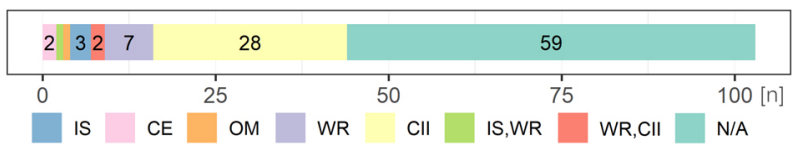

Fig. 6. Part of the Franziscean cadastre involved in the study.

IS - indication sketches, CE - Cadastral Elaborat, OM original maps, WR - written registry, CII - Compulsory Imperial imprints, N/A - not available. from other parts (e.g. figures, examples of the maps used) of the records (Fig. 6). We have identified the 28 records based solely on Compulsory Imperial imprints. Other parts of the Franziscean cadastre were employed with minimum frequency. The same situation was identified in the case of a combination of the particular sources (Fig. 6).

\section{Other data, map sources and GIS processing}

We have addressed the question of digitalization and GIS processing of the records that use any map sources of the Franziscean cadastre (subset of 85 records) by searching for comments on the method of digitization (in the means of vector layer creation) of the LULC classes from the map source and georeferencing (or another form of adjusting maps to coordinate systems) methods. Most of the records $(n=48)$ explicitly mentioned both of the methods. Two records only mentioned georeferencing, and fourteen only mentioned vectorization. Nineteen works do not include any comments about such methods anywhere in the text.

As regarding the georeferencing methods, only fraction of the records (less than $25 \%$ of the works that refers to geoprocessing methods) explicitly mentions the i) method of transformation (usually affine or polynomial), ii) the error of transformation (RMSE), iii) methods of control points location and processing or iv) used coordinate system and projection. Rest of the records $(n=36)$ describe just use of the method without any further information about detailed settings.

The most frequent group of other (complementary/main) sources used in the records were orthophotomaps or aerial imagery in the case of older sources (Fig. 7). For the sake of clarity, the

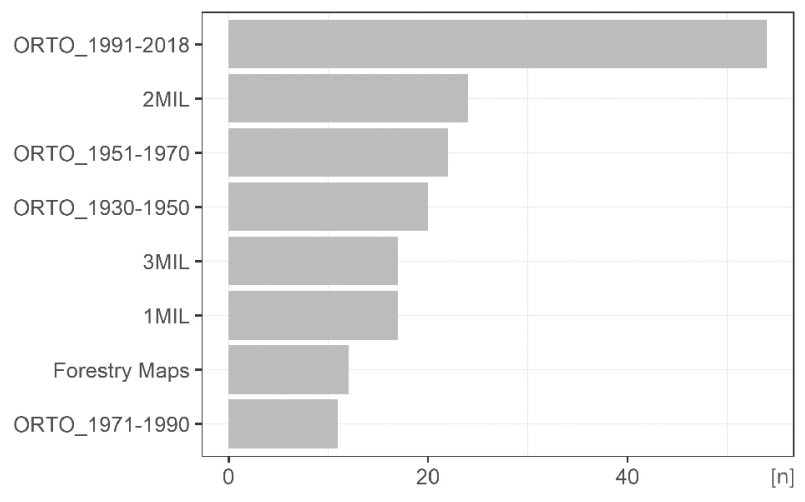

Fig. 7. Frequency of the supplementary data sets used. ORTO - orthophoto, MIL - Millitary mapping. 
orthophotomaps used in the studies were grouped into intervals according the periods of their origin (1930-1950-1970-1990-2018). The last period of 1991-2018 was involved in most cases $(n=54)$, followed by the periods of 1951-1970 ( $\mathrm{n}=22), 1930$ $1950(n=20)$ and 1971-1990 $(n=11)$. The second major group of other sources formed maps of old Military mapping $\left(1^{\text {st }}=16,2^{\text {nd }}=23\right.$ and $\left.3^{\text {rd }}=16\right)$. Lastly, we have found a group of 12 records reporting the use of forestry maps of a different age.

Figure 8 shows the share of the particular combination of the individual sources (e.g. $8 \%$ of the records use data from Franziscean cadastre together with II. Military mapping and combination of the I. and III. Military mapping. Concerning the other data and map sources, the exploration of the association among particular sources resulting to the most common combination of Franziscean cadastre with current (ORTO_1991-2018) and older (ORTO_1951-1970; ORTO_1930-2050) orthophotomaps. Up to $10 \%$ of records used any combination of older and current orthophotomaps (see Fig. 8) and a combination of the Franziscean cadastre with maps of Military mapping.

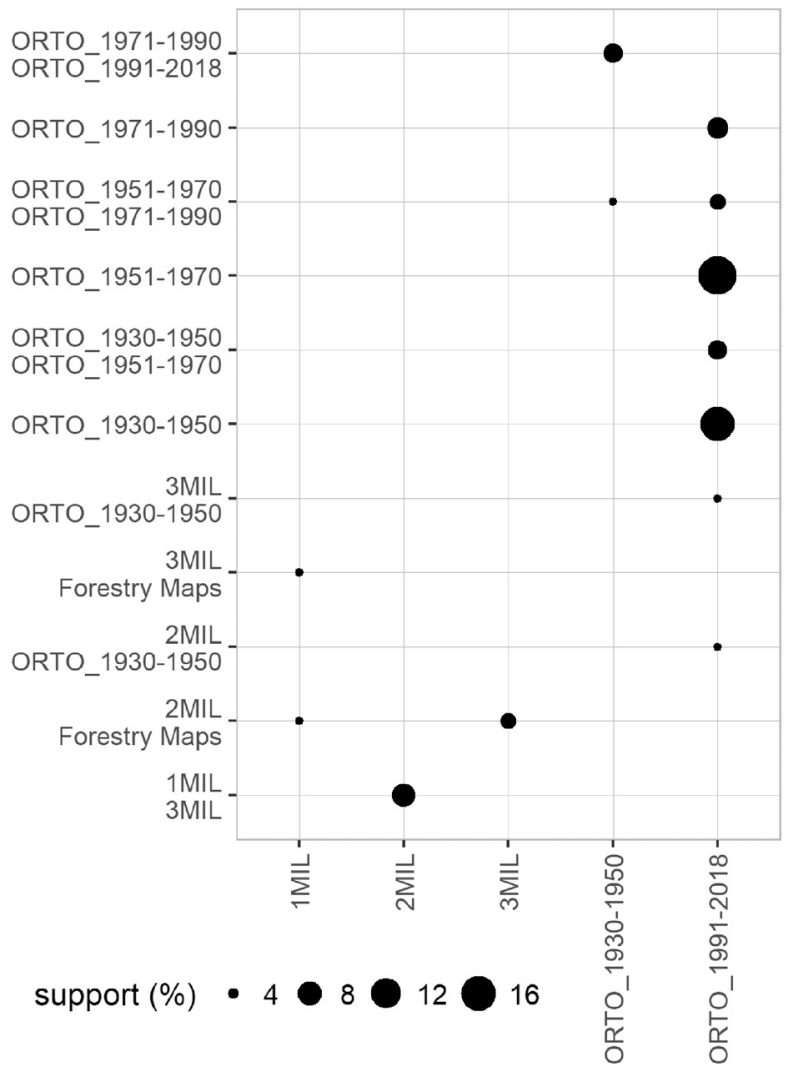

Fig. 8. Association between map and data sources. MIL - Military mapping, ORTO - orthophoto/aerial imagery.

\section{Spatial scale of the studies}

The spatial extent of the studies was the last investigated feature. We have divided the spatial extent into categories of state of the application (Fig. 1), territorial units and explicit acreage reported by authors. As regards the territorial units, we followed the division to administrative units. We observed a majority on the lowest level of administrative division - cadastral districts (42). With the upscaling and the need for more robust databases of particular research, the numbers of records decreased (municipality - 4, district -11 , county -9 , state -10 ). Not all studies were designed to fit in the administrative units. Therefore, we enriched the spatial scale by river (16), river basin (4), forest (1), protected landscape area (3) and mountain range (1). The explicitly mentioned acreage of the studied area was mentioned by 32 records. The area ranged from 0.23 to $12,200 \mathrm{~km}^{2}$ with the median value of $47.62 \mathrm{~km}^{2}$.

\section{Discussion}

The use of historical cadastral records and maps gains the attention in landscape reconstruction and landscape research in general, and the Franziscean cadastre with its broad spatial extent does not stand as an exception. Critical reflection on the use of such a historical source is of major importance due to possible difficulties that could be rendered by mistreatment of inferred spatial and non-spatial data. Therefore, we concentrated our efforts on reviewing the records where the Franziscean cadastre was used addressing fields of processing and extraction of the data, application aims, the context of supplementary data and its spatial extent.

The significant growth of the records towards the doubled number in 2013 was observed. The possible explanation of the increasing trend lies (besides the general increase of scientific records published) in the digitalization of the map sheets and the often better accessibility of the Franziscean cadastre archival records. According to our knowledge, there is no initiative that covers all parts of the Franziscean Cadastre (e.g. written registry, Compulsory Imperial imprints, indication sketches, etc.) for the territory of the entire former empire. On the scale of the entire empire, 
the closest initiative dealing with the accessibility of map sources is the MAPIRE project originating in Hungary (Biszak et al. 2017). The online accessibility of map sources has been partly or completely solved for the territory of Czechia since 2008 (ÚAZK 2018), Austria (Kugler, Schönweiler 2014) and Galicia since 2012 (Osborn 2013).

As mentioned in the section dealing with the methods of records query, the issue of inconsistent naming of the FC is present. According to our findings, there are differences between countries - most significantly Czechia with impropriate term Stable or Stabile referring to stability of the cadastre in legal documents as ÖNB (2018). Therefore, we put forward the question of using the more apposite term Franziscean cadastre.

Interesting heterogeneity has been found considering the results of the major and detailed aims of the records. The question of categorization is never easy one due to the individuality of the works that often spans over borders of different categories and intrinsic artificiality of the categories. In our case, this issue is reflected by the first category (landscape change), where the works dealing with persistent landscape elements were embodied. These persistent features are often formed by a particular LULC class. Therefore, we could categorize them as studies dealing with, for example, agricultural land. Despite the possible pitfalls we outline trends in the use of the Franziscean cadastre in (i) general landscape and LULC trajectories researched, (ii) river morphology and dynamics and (iii) agricultural, forestry and agroforestry assessment.

Concerning the particular source of the Franziscean cadastre, the majority of studies used only maps (more precisely, Compulsory Imperial imprints). We hypothesize that the higher frequency of the use of Compulsory Imperial imprints in Czechia is based on the availability of digital form this particular source in comparison to other map sources (original maps, indication sketches) that have digital form available rather newly. Written registry, protocols and combination of partial sources were present in minor subset. Not much attention has been paid to the verification of the LULC classification coherence in the written registry and map sources. Krčmářová (2015) found minor differences in the LULC classes recorded for single plots (discrepancy of arable land/agroforestry in map and written source). In accordance with the findings of such discrepancies, Woitschová (2017: 118) stressed the two possible issues connected with the use of historical map documents. Historical maps could be either the result of the author's wishful thinking or a deliberately fail to reflect the reality as an effort to use maps as a projection of results in the first case and cheating in the tax calculation in second case. Given the fact that there are more than four particular parts of the Franziscean cadastre (indication scratches, original maps, Compulsory Imperial imprints, written registry of land and building parcels and documents of valuation), the possible uncertainty in LULC classes delimitation should be further assessed and approached with the criticism inherent to historians. Trpáková and Trpák (2009) stressed another possible source of errors in the interpretation of LULC based on the chronological discrepancy of the individual parts of the Franziscean cadastre (e.g. difference of 20 years between the map and Cadastral elaborate). The yield valuation protocols, which are rich in detailed information about land-uses, are very much underused (Krčmářová, Arnold 2016). A frequently suggested approach to overcome the outlined pitfall lies in the cross-checking or cross validation of the historical data (Kienast 1993, Yang et al. 2014) with other historical datasets (e.g. Fescenko et al. 2016).

The number of applied time points and their chronological ordination implies questions of chronological sampling adequacy and comparability. Firstly, we have found that the majority of the records employed three time points of the Franziscean cadastre together with the current (1991-2018) and older orthophoto (1930-1950 and 1951-1970). Based on this division, there is significant inequality of the time range in the means of the length of the researched periods that often cannot be bridged due to a lack of sufficient spatial data (e.g. the end of $19^{\text {th }}$ century). The other comment on the use of multi-temporal data aims to an, often strict, assessment of the flow of the landscape change with the data that represents the landscape structure for a particular year that can consecutively lead to periodization with strict boundaries or milestones (see also LeGoff 2015, Brook, Bowman 2006). Secondly, handling with different spatial data types (e.g. maps and aerial imagery, as it was recognized as a rather common data mixture - see Fig. 8) there 
is the intrinsic issue of the comparability of results based on the generalization of the thematic resolution (Yang et al. 2014). If we consider the broad LULC thematic (classes) resolution of the Franziscean cadastre and the individual research focus of the records, as it is apparent from summary of LULC categories applied in the records (Table 1), the thematic resolution was generalized (e.g. merger of coniferous and mixed forest to one general category of forest) to some extent in the majority of the records and could lead to loss of information.

Lastly, Leyk et al. (2005) mention the possible source of errors in the processing of the historical map sources (see also Strzelecki, 2013). The processing in the means of the studied records is often based on the digitalization of the map source, the georeferencing of the map sheet and the digitization (vectorization) of the parcels with particular LULC in GIS or similar software (however we understand that proliferation of these methods by the first year mentioned in our study can be questionable despite the fact that the tools were used since 1990s; c.f. Apan, Peterson 1998) According to our results, more than $20 \%$ of the works did not describe the methods of digitization and extraction of the LULC layers. Therefore, it is not possible to reflect the potential source of error based, for example, on a large minimal mapping unit or the absence of transformation of the map sheet.

\section{Concluding remarks}

In this study focused on the use of the Franziscean cadastre in landscape research, we have outlined several questions excerpting (i) the purpose of the study, (ii) the practice of processing/manipulating the source and extraction of LULC information and (iii) complementary data used alongside the Franziscean cadastre.

We claim that our findings will be a contribution to discussion about sampling adequa$\mathrm{cy}$, the quality of historical data, the selection of data sources, and archival data processing in landscape reconstruction and development research. As regards the bibliographic and formal information we have discussed, the dominance of the studies originated in Czechia. This fact is probably driven by the availability of the
Franziscean cadastre datasets in digital form. Such dominance implies the issue of the inappropriate terming stable cadastre used exclusively by Czech and Slovak scholars. On the basis of our findings, we can identify a very broad range of purposes or aims of the records where the data of a stable cadastre are of use due to an abundance of detailed data provided by the FC. Despite the preciseness of the FC, close attention should be paid to the five special features that could be detrimental to the outcomes of future research dealing with the FC and that we based on findings from our review:

Missing description of the source / Consistency of the FC - we have found the absence of a description of the partial source of the FC used. This issue could lead to the twofold problem of i) general reproducibility of the record's outcomes (where we don't know, for example, the exact map source used, that displays very different LULC as Trpáková and Trpák (2009) showed) and ii) general comparability of the partial sources of the FC that could be bridged by cross-checking or cross-validating the data.

Although the FC consists of many documents, the most used source, if specified, were the Compulsory Indication imprints. Thus, other parts of the FC are underused. Moreover, further analysis of connections between all parts of the FC is needed.

Absence of the spatial data processing description - again, this issue could lead to serious problems in the replicability of records. This issue could be easily resolved by the simple description of the GIS/Photogrammetric methods that were of use.

In the case of landscape change studies, there is the ongoing question of chronological sampling adequacy in the means of the possibility to capture all breaks in the continuity of the particular LULC classes or landscape structure. We are arguing in the general sense that individual time points should be perceived more like probes to the possible process of landscape change. Therefore, it is very difficult to reconstruct the change of LULC in a detailed scale, for example, from three time points. After the mechanical use of three time horizons (1840s-1950s-2000s) with only the Compulsory Imperial imprints representing the first horizon, we suggest the detailed and less schematic use of the data sources. One 
option could be to precise the development by squeezing in more horizons or to precise the landscape situation in one time horizon.

Lastly, there are more methodological issues connected with the complementarity of the orthophotomaps as visually interpreted sources of LULC and survey-based maps of old cadastres. The combination of orthophotomaps and survey-based maps could be burdened by errors from both sides. Following Leyk et al. (2005), the source of error could be rooted in the production of the maps (issues during survey and reproduction), transformation (here, the processing of the maps, e.g. georeferencing) and application (different semantics of LULC delimitation - here, consistency of appropriate visual interpretation of LULC class on orthophotomaps and meaning of LULC class in the FC).

\section{Acknowledgments}

We thank three anonymous reviewers and colleague Pavel Raška for comments that greatly improved the manuscript.

\section{Author's contribution}

M.D. and M.F. conceived the original idea of research design, structure for data acquisition, acquisition itself and consecutive data analysis. M.D. wrote the manuscript with support from M.F.

\section{References}

Affek A., 2015. Spatially explicit changes in land ownership through 3 socio-political systems: A case study from southeast Poland. Geographia Polonica 88(3): 519-530. DOI 10.7163/GPol.0032.

Agnoletti M., 2007. The degradation of traditional landscape in a mountain area of Tuscany during the 19th and 20th centuries: Implications for biodiversity and sustainable management. Forest Ecology and Management 249: 5-17. DOI 10.1016/j.foreco.2007.05.032.

Apan A.A., Peterson J.A., 1998. Probing Tropical Deforestation. Applied Geography 18(2): 137-52.

Bender O., Boehmer H.J., Jens D., Schumacher K.P., 2005. Using GIS to analyse long-term cultural landscape change in Southern Germany. Landscape and Urban Planning 70: 111-125. DOI 10.1016/j.landurbplan.2003.10.008.

Beranová L., Balej M., Raška P., 2017. Assessing the geotourism potential of abandoned quarries with multitemporal data (České Středohoří Mts., Czechia). GeoScape 11(2): 93-111. DOI 10.1515/geosc-2017-0008.

Bičík I., Anděl J., Balej M., 2010. Landscape Function Transformations with Relation to Land-Use Changes. In: J. Anděl, I. Bičík, P. Dostál, Z. Lipský, S.G. Shahneshin (eds.), Landscape Modelling. Springer Netherlands, Dordrecht: 87-103. DOI 10.1007/978-90-481-3052-8_7.

Bíl M., Krejčí O., Bílová M., Kubeček J., Sedoník J., Krejčí V., 2014. A chronology of landsliding and its Impacts on the Village of Halenkovice, Outer Western Carpathians. Geografie 4: 342-363.

Biszak E., Biszak S., Timár G., Nagy D., Molnár G., 2017. Historical topographic and cadastral maps of Europe in spotlight - Evolution of the MAPIRE map portal. Proc. 12th ICA Conf. Digit. Approaches to Cartogr. Heritage, Venice, 26-28 April 2017: 204-208.

Breschi M., Fornasin A., Manfredini M., Pozzi L., Rettaroli R., Scalone F., 2014. Social and Economic Determinants of Reproductive Behavior Before the Fertility Decline. The Case of Six Italian Communities During the Nineteenth Century. European Journal of Population 30: 291-315. DOI 10.1007/s10680-013-9303-8.

Brook B.W., Bowman D.M.J.S., 2006. Postcards from the past: charting the landscape-scale conversion of tropical Australian savanna to closed forest during the 20th century. Landscape Ecology 21: 1253-1266. DOI 10.1007/s10980006-0018-7/

Bumba J., 2007. České katastry od 11. do 21. století. Grada.

Dale P., Mclaughlin J. D., 2000. Land Administration. Oxford University Press, Oxford.

Dolák L., Brázdil R., Valášek H., 2015. Impacts of Hydrometeorological Extremes in the Bohemian-Moravian Highlands in 1706 - 1889 As Derived From Taxation Records. Geografie 120: 465-488.

Ebel M., 2004. Stabilní katastr a jeho využití pro dějiny staveb. Dějiny staveb 1: 5-14.

Fescenko A., Lukins M., Fescenko I., 2016. Validation of medium-scale historical maps of Southern Latvia for evaluation of impact of continuous forest cover on the present-day mean stand area and tree species richness. Baltic Forestry 22(1): 51-62.

Feucht R., 2008. Flächenangaben im österreichischen Kataster. Diploma Thesis. Technischen Universität Wien.

Foley J.A., DeFries R., Asner G.P., Barford C., Bonan G., Carpenter S.R., Chapin F.S., Coe M.T., Daily G.C., Gibbs H.K., Helkowski J.H., Holloway T., Howard E.A., Kucharik C.J., Monfreda C., Patz J.A., Prentice I.C., Ramankutty N., Snyder P.K., 2005. Global Consequences of Land Use. Science 5734(309): 570-574.

Forejt M., Dolejš M., Raška P., 2018. How reliable is my historical land-use reconstruction? Assessing uncertainties in old cadastral maps. Ecological Indicators 94: 237-245. DOI 10.1016/j.ecolind.2018.06.053.

Forejt M., Skalos J., Pereponova A., Plieninger T., Vojta J., Šantrůčková M., 2017. Changes and continuity of wood-pastures in the lowland landscape in Czechia. Applied Geography 79: 235-244. DOI 10.1016/j.apgeog.2016.12.016.

Fraňková E., Cattaneo C., 2018. Organic farming in the past and today: sociometabolic perspective on a Central European case study. Regional Environmental Change 18(4): 951-963. DOI 10.1007/s10113-016-1099-8.

Fuchs R., Verburg P. H., Clevers J. G. P. W., Herold M., 2015. The potential of old maps and encyclopaedias for reconstructing historic European land cover/use change. Applied Geography 59: 43-55. DOI 10.1016/j.apgeog.2015.02.013.

Glavan M., Miličić V., Pintar M., 2013. Finding options to improve catchment water quality-Lessons learned from historical land use situations in a Mediterranean catch- 
ment in Slovenia. Ecological Modelling 261-262: 58-73. DOI 10.1016/j.ecolmodel.2013.04.004.

Hahsler M., Grün B., Hornik K., 2005. arules - A Computational Environment for Mining Association Rules and Frequent Item Sets. Journal of Statistical Software 14(15): 1-25. DOI 10.18637/jss.v014.i15.

Hamre L. N., Domaas S. T., Austad I., Rydgren K., 2007. Land-cover and structural changes in a western Norwegian cultural landscape since 1865, based on an old cadastral map and a field survey. Landscape Ecology 22(10): 1563-1574. DOI 10.1007/s10980-007-9154-y.

Harvey F., Kaim D., Gajda A., 2014. Analysis of historical change using cadastral materials in the carpathian foothills. European Journal of Geography 5(3): 6-21.

Hohensinner S., Lager B., Sonnlechner C., Haidvogl G., Gierlinger S., Schmid M., Krausmann F., Winiwarter V., 2013. Changes in water and land: the reconstructed Viennese riverscape from 1500 to the present. Water History 5(2): 145-172. DOI 10.1007/s12685-013-0074-2.

Kaim D., Kozak J., Ostafin K., Dobosz M., Ostapowicz K., Kolecka N., Gimmi U., 2014. Uncertainty in Historical Land-Use Reconstructions with Topographic Maps. Quaestiones Geographicae 33(3): 55-63. DOI 10.2478/quageo-2014-0029.

Kain R. J. P., Baigent E., 1992. The Cadastral Map in the Service of the State: A History of Property Mapping. Chicago: University of Chicago Press.

Karásek P., Tlapáková L., Podhrázská J., 2015. The Location and Extent of Systematic Drainage in Relation to Land Use in the Past and at Present and in Relation to Soil Vulnerability to Accelerater Infiltration in the Protected Landscape Area Železné Hory. Acta Universitatis Agriculturae et Silviculturae Mendelianae Brunensis 63(4): 1121-1131.

Kienast F., 1993. Analysis of historic landscape patterns with a Geographical Information System? a methodological outline. Landscape Ecology 8(2): 103-118. DOI 10.1007/ BF00141590.

Kolejka J., 2010. Post-industrial landscape - its identification and classification as contemporary challenges faced by geographic research. Geographia Technica 12(2): 67-78.

Krausmann F., 2008. Land Use and Socio-economic Metabolism in Pre-industrial Agricultural Systems : Four Nineteenth-century Austrian Villages in Comparison. Social Ecology Working Paper 72 (December).

Krčmářová J., 2015. Forgetting traditional agricultural knowledge in modernization. Interdisciplinry historical reconstruction of Czech agroforestry. PhD thesis, FHSUK, Praha.

Krčmářová J., Arnold M., 2016. Traditional Agriculture as Cultural Heritage. Forgotten Agroforestry Practices Recorded in Textual Part of Nineteenth Century Tax Records. In: M. Agnoletti, F. Emanueli (eds.), Biocultural Diversity in Europe. Environmental History, Springer, vol. 5: 211-231. DOI 10.1007/978-3-319-26315-1_11.

Krčmářová J., Jeleček L., 2017. Czech traditional agroforestry: historic accounts and current status. Agroforestry Systems 91(6): 1087-1100. DOI 10.1007/s10457-016-9985-0.

Kugler R., Schönweiler F., 2014. Digitalization of the Franciscan Cadastral Survey (1817-1861). Working paper No. 17/16. United Nations Working Group on Geographical Names.

LeGoff J., 2015. Must We Divide History into Periods? (English translation). Columbia University Press, New York.

Leyk S., Boesch R., Weibel R., 2005. A conceptual framework for uncertainty investigation in map based land cover change modelling. Transactions in GIS 9(3): 291-322. DOI 10.1111/j.1467-9671.2005.00220.x.

Moher D., Liberati A., Tetzlaff J., Altman D. G., 2009. Preferred Reporting Items for Systematic Reviews and Meta-Analyses: The PRISMA Statement. PLoS Medicine 6(7): e1000097. DOI 10.1371/journal.pmed.1000097.

ÖNB [Österreichische Nationalbibliothek], 2018. Grundsteuerpatent 1817. Politische Gesetze und Verordnungen Franz I 1792-1848. Online: alex.onb.ac.at/ [accessed 16 May 2018].

Osborn J., 2013. Gesher Galicia' s Online Cadastral Map Room: Evolution and Opportunities. ENArC/ICARUS Workshop: Cartography and Cadastral Maps, Scuola Normale Superiore. Pisa.

Pacina J., Holá M., 2014. Settlement identification in abandoned borderland. 14th SGEM GeoConference on Informatics, Geoinformatics and Remote Sensing 1: 769-776. DOI 10.5593/SGEM2014/B21/S8.099.

Pavelková R., Frajer J., Havlíček M., Netopil P., Rozkošný M., David V., Dzuráková M., Šarapatka B., 2016. Historical ponds of the Czech Republic: an example of the interpretation of historic maps. Journal of Maps 12: 551-559. DOI 10.1080/17445647.2016.1203830.

Popelka S., Dedkova P., 2014. Extinct Village 3D visualization and its Evaluation with Eye-Movement Recording. In: B. Murgante, S. Misra, A.M.A.C. Rocha, C. Torre, J.G. Rocha, M.I. Falcão, D. Taniar, B.O. Apduhan, O. Gervasi (eds.), Computational Science and Its Applications - ICCSA 2014. Lecture Notes in Computer Science, Springer, Cham, vol 8579: 786-795. DOI 10.1007/978-3-319-09144$0 \_54$.

Quaranta L., 2011. Agency of Change: Fertility and Seasonal Migration in a Nineteenth Century Alpine Community. European Journal of Population / Revue européenne de Démographie 27(4): 457-485. DOI 10.1007/s10680-011-9241-2.

R Core Team, 2017. R: A language and environment for statistical computing. R Foundation for Statistical Computing, Vienna, Austria.

Raška P., Dolejš M., Hofmanová M., 2017. Effects of Damming on Long-Term Development of Fluvial Islands, Elbe River (N Czechia). River Research and Applications 33(4): 471-482. DOI 10.1002/rra.3104.

Raška P., Zábranský V., Brázdil R., Lamková J., 2016. The late Little Ice Age landslide calamity in North Bohemia: Triggers, impacts and post-landslide development reconstructed from documentary data (case study of the Kozí vrch Hill landslide). Geomorphology 255: 95-107. DOI 10.1016/j.geomorph.2015.12.009.

Rockström J., Steffen W., Noone K., Persson Å., Chapin F. S. I., Lambin E., Lenton T. M., et al., 2009. Planetary Boundaries: Exploring the Safe Operating Space for Humanity. Ecology and Society 14(2): art32. DOI 10.5751/ES-03180140232

Scorpio V., Zen S., Bertoldi W., Surian N., Mastronunzio M., Dai Prá E., Zolezz, G., Comiti F., 2018. Channelization of a large Alpine river: what is left of its original morphodynamics? Earth Surface Processes and Landforms 43(5): 1044-1062. DOI 10.1002/esp.4303.

Skaloš J., Kašparová I., 2012. Landscape memory and landscape change in relation to mining. Ecological Engineering 43: 60-69. DOI 10.1016/j.ecoleng.2011.07.001.

Skaloš J., Keken Z., Justová H., Křováková K., Chaurová H., 2014. Classification System for Monitoring Historic Changes in Forest and Non-Forest Woody Vegeta- 
tion-A Basis for Management. Open Journal of Forestry 4(1): 75-84. DOI 10.4236/ojf.2014.41012.

Sklenička P., Charvátová E., 2003. Stand continuity -a useful parameter for ecological networks in post-mining landscapes. Ecological Engineering 20(4): 287-296. DOI 10.1016/S0925-8574(03)00053-3.

Sklenička P., Zouhar J., Trpáková I., Vlasák J., 2017. Trends in land ownership fragmentation during the last 230 years in Czechia, and a projection of future developments. Land Use Policy 67: 640-651. DOI 10.1016/j.landusepol.2017.06.030.

Strzelecki K. 2013. 18th Century Vistula River Geography in View of Franciszek Florian Czaki's Maps. Quaestiones Geographicae 32(1): 27-32. DOI 10.2478/quageo-2013-0004.

Svobodová K., Hájek T., 2017. Pilgrimage route recovery in an industrial landscape. Journal of Environmental Planning and Management 60(6): 959-976. DOI 10.1080/09640568.2016.1189818.

Szabó P., Hédl R., 2013. Socio-Economic Demands , Ecological Conditions and the Power of Tradition: Past Woodland Management Decisions in a Central European Landscape. Landscape Research 38(2): 243-261.

Szturc J., Karásek P., Podhrázská J., 2017. Historical Changes in the Land Use Connected with Appropriation of Agricultural Land - Case Study of Cadastral Areas Dolní Věstonice and Modřice (Czech Republic). European Countryside 9(4): 658-678. DOI 10.1515/euco-2017-0038.

Timár G., Biszak S., 2010. Digitizing and georeferencing of the historical cadastral maps (1856-60) of Hungary. 5th International Workshop on Digital Approaches in Cartographic Heritage. Vienna, Austria, 22-24 February 2010. 22-24.

Tlapáková L., Karásek P., Stejskalová D., 2013. Retrospective Evaluation of the Extent and Spatial Changes of Realized
Hydromelioration Systems. Polish Journal of Environmental Studies 22(6): 1855-1862.

Treml V., Migoń P., 2015. Controlling factors limiting timberline position and shifts in the Sudetes: A review. Geographia Polonica 88(2): 55-70. DOI 10.7163/GPol.0015.

Troll M., Ostafin K., 2016. Use of late 18th and early 19th century cadastral data to estimate past forest cover change - a case study of Zawoja village. Prace Geograficzne 146: 31-49. DOI 10.4467/20833113PG.16.016.5546.

Trpáková I., Trpák P., 2009. Úskalí analýzy a ekologické interpretace starých mapových děl na modelovém př́kladu mapových a písemných částí stabilního katastru. Geo/ bio diverzita - integrující perspektivy. In: Romportl, D. Chuman, T. (eds.): Sborník abstraktů z výroční konference CZ - IALE, Univerzita Karlova, Praha.

ÚAZK [Ústřední Archiv Zeměměřictví a Katastru], 2018. ÚAZK Central Archive of Surveying and Land Register Online: archivnimapy.cuzk.cz (accessed 15 May 2018).

Wickham H, 2009. ggplot2: Elegant Graphics for Data Analysis. Springer-Verlag New York.

Wickham H., 2011. The Split-Apply-Combine Strategy for Data Analysis. Journal of Statistical Software 40(1): 1-29.

Woitschová K., 2017. Hidden Treasures: Challenging Traps of Historical Sources for Environmental History. In E. Vaz, C. Joanaz de Melo, L.M. Costa Pinto (eds.), Environmental History in the Making 6: 109-122. DOI 10.1007/9783-319-41085-2_7.

Yang Y., Zhang S., Yang J., Chang L., Bu K., Xing X., 2014. A review of historical reconstruction methods of land use/ land cover. Journal of Geographical Sciences 24(4): 746-766. DOI 10.1007/s11442-014-1117-z.

Žiberna I., 2015. Natural geographical features and land use in the municipality of Zavrč. Geografski pregled 36: 51-64. 
Supplement 1. List of features extracted from the records.

\begin{tabular}{|c|c|c|c|}
\hline Group & Feature & Description & Categories, Values (min.-max., SD) \\
\hline \multirow{5}{*}{ 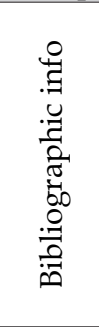 } & Keyword & $\begin{array}{l}\text { Database keyword } \\
\text { used for search for } \\
\text { record }\end{array}$ & $\begin{array}{l}\text { Franziszeischer Kataster, Franciscian Cadastre, Stable Ca- } \\
\text { dastre, Stabile Cadastre, Franciscan Cadastre, Františkánský } \\
\text { katastr, Stabilní katastr and Austrian cadastre }\end{array}$ \\
\hline & Type & Type of the record & Article, Conference proceedings, Book Chapter, Review \\
\hline & Year & Year of publishing & $2000-2018,3.54$ \\
\hline & Article keywords & $\begin{array}{l}\text { Keywords used in } \\
\text { record }\end{array}$ & Comma delimited text \\
\hline & State & Place of case study & Czechia, Croatia, Austria, Italy, Poland, Slovakia, Slovenia \\
\hline \multirow{4}{*}{ 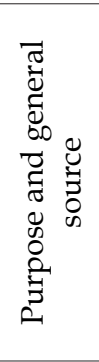 } & Cadastral maps & $\begin{array}{l}\text { Indication of cadastral } \\
\text { maps use }\end{array}$ & YES/NO \\
\hline & Written registry & $\begin{array}{l}\text { Indication of written } \\
\text { registry use }\end{array}$ & YES/NO \\
\hline & $\begin{array}{l}\text { Purpose of the } \\
\text { study - general }\end{array}$ & $\begin{array}{l}\text { General categories of } \\
\text { the purpose }\end{array}$ & $\begin{array}{l}\text { Landscape - general category; Streams and water bodies; } \\
\text { Agricultural land; Forests, Forestry; Reconstruction models; } \\
\text { Ownership and property rights; Demography }\end{array}$ \\
\hline & $\begin{array}{l}\text { Purpose of the } \\
\text { study - detailed }\end{array}$ & $\begin{array}{l}\text { Detailed description } \\
\text { of the purpose }\end{array}$ & $\begin{array}{l}\text { Text description (e.g. stream and water bodies localization, } \\
\text { land use / land cover change }\end{array}$ \\
\hline \multirow{10}{*}{ 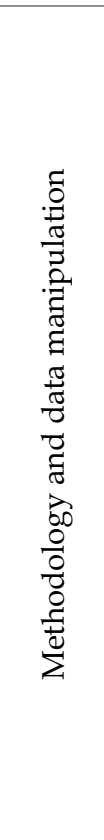 } & Multitemporality & $\begin{array}{l}\text { Application of multi- } \\
\text { ple time segments }\end{array}$ & YES/NO \\
\hline & $\begin{array}{l}\text { Number of time } \\
\text { points }\end{array}$ & $\begin{array}{l}\text { Number of time seg- } \\
\text { ments applied }\end{array}$ & $1-16,2.73$ \\
\hline & Years of time points & $\begin{array}{l}\text { Years of time seg- } \\
\text { ments used }\end{array}$ & 1529-2016, 97.61 \\
\hline & Other map sources & $\begin{array}{l}\text { Categorization of } \\
\text { other map sources }\end{array}$ & $\begin{array}{l}\text { abbreviation of map source (e.g. } 2 \mathrm{MIL} \text { - Second military } \\
\text { mapping, ORTO_1991-2018 - orthphoto originating from } \\
\text { 1991-2018) }\end{array}$ \\
\hline & Other data sources & $\begin{array}{l}\text { Categorization of } \\
\text { other data sources }\end{array}$ & $\begin{array}{l}\text { abbreviation of data source (e.g. URB - Urbaria, FS - Field } \\
\text { Survey, SCH - Soil Chemistry) }\end{array}$ \\
\hline & Type of LULC & $\begin{array}{l}\text { LULC categories } \\
\text { extracted, applied }\end{array}$ & $\begin{array}{l}\text { full name of category provided by author (i. e. Vineyards, } \\
\text { Arable land with fruit trees) }\end{array}$ \\
\hline & $\begin{array}{l}\text { Number of LULC } \\
\text { classes }\end{array}$ & $\begin{array}{l}\text { Count of distin- } \\
\text { guished LULC classes }\end{array}$ & $0-12,3.24$ \\
\hline & LULC - map & $\begin{array}{l}\text { LULC classes derived } \\
\text { solely from map }\end{array}$ & YES/NO \\
\hline & $\begin{array}{l}\text { Georefference of } \\
\text { map Sheet }\end{array}$ & $\begin{array}{l}\text { Indicated GIS manip- } \\
\text { ulation mentioned }\end{array}$ & YES/NO \\
\hline & $\begin{array}{l}\text { Vectorization/digi- } \\
\text { tization of map }\end{array}$ & $\begin{array}{l}\text { Indicated GIS manip- } \\
\text { ulation mentioned }\end{array}$ & YES/NO \\
\hline \multirow{2}{*}{ 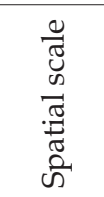 } & Scale of the study & $\begin{array}{l}\text { Spatial scale of the } \\
\text { study }\end{array}$ & $\begin{array}{l}\text { administrative scales - Cadastre, Municipality, County, } \\
\text { Region, State; individual scales - mountain range, protected } \\
\text { area, river, river basin }\end{array}$ \\
\hline & $\begin{array}{l}\text { Explicit scale of the } \\
\text { study }\end{array}$ & $\begin{array}{l}\text { Acreage under study } \\
\text { as reported by authors }\end{array}$ & $0.23-12,200,2111.29(n=32)$ \\
\hline
\end{tabular}

